\title{
Motivations and Ways for Multi-National Corporation's Tax Planning
}

\author{
Caiying Tian \\ School of Accounting, Shandong Economic University \\ Jinan 250014, China \\ E-mail: tcying999@tom.com
}

\begin{abstract}
Taxes can cause a decrease of cash flows of multi-national corporations. Therefore, to take advantages of countries' different tax systems and adopt kinds of measures to reduce taxes is meaningful for multi-national corporations increasing the cash flow and improving the competitiveness.
\end{abstract}

Keywords: Multi-national corporation, Tax planning

\section{Motivations for multi-national corporations tax planning}

To actualize the maximum net income or the minimum taxes is the subjective motivation for multi- national corporations performing international tax planning. Tax differences of countries serve as the objective reason for multinational corporations performing international tax planning. Tax differences mainly include:

\subsection{Different definitions of taxpayer cause differences of taxes}

Concerning the tax liability, there are two fundamental principles in the world. The first is the principle of personality that a person should pay taxes to the country where he or she lives or a person should pay taxes to the country that he or she belongs to. The second is the principle of territoriality that a person should pay taxes to the country where he or she gets the income or wealth. If the tax jurisdiction is based on the principle of territoriality, taxes are merely imposed on all taxable incomes from the country. If the tax jurisdiction is based on the principle of personality, taxes are imposed on taxpayers' all taxable incomes from the world. Countries follow different principles and may disagree with the definition of taxpayer, which generates lots of chances for international tax planning.

\subsection{Countries impose different taxations}

Most countries impose income taxes on individuals and corporate legal persons but treat the transfer income of properties differently. For example, some countries do not impose taxes on the transfer income of properties. Even if impose income taxes on individuals and corporations, countries may adopt different rates. For example, some countries adopt the proportional tax rate and some the excess progressive of tax rate. Therefore, tax burden differs among countries.

\subsection{Different tax bases and tax rates}

For taxpayers, different countries regulate similarly on the same tax type. But for tax bases, countries regulate differently. As a result, the same tax type has a narrow or wide tax base in different countries. Taxpayers have to pay taxes differently. For the income tax, countries regulate different rates. The rate in some countries reaches $50 \%$ and that in certain countries is less than $30 \%$. All these facts serve as preconditions for tax planning.

\subsection{Different regulations on double taxation}

International double taxation means two or more countries impose same or similar taxes on the same taxpayer or different taxpayers for same tax type during certain period. In order to reduce the negative effects of international double taxation on taxpayers, all countries take some measures, such as the popular tax credit method and tax exemption method. However, because of the different methods adopted by countries, chances of decreasing taxes are various.

In addition, differences of anti-tax avoidance methods, tax preferences, tax laws, and other non-tax aspects in different countries serve as chances for multi-national corporations performing tax planning. 


\section{Main methods for multi-national corporations tax planning}

\subsection{Avoid being a residential company of high-tax countries}

If a multi-national corporation is regarded as a residential company by one country, it must take a comprehensive tax liability to the country. In other words, the corporation should pay taxes for its income from the world. Therefore, the residential company in a high-tax country has to pay higher taxes than that in a low-tax country. Multi-national corporations can reduce its international taxes by avoiding being a residential company of high-tax country. Because different countries have different identification standards for a residential company, taxpayers should take different measures. For example, American tax law regulates that all companies registered by America Federal or State laws are the "legal residents" of America, no matter whether the management institutions locate in America or not, and no matter whom the stock right belongs to. Therefore, in order to pay less tax in America, the only way is to avoid being a "legal resident" of America.

\subsection{Select favorable foreign operations}

As a multi-national corporation determines to invest in foreign countries or start businesses, it has two kinds of operations: build a permanent establishment or form a child company. To form a branch agency has five advantages in the tax aspect as follow. (1) The branch is merely a subsidiary unit or agency of the general corporation outside. The complicated register procedures in the host country are not necessary. And it does not pay the capital register tax and the stamp tax. (2) The general corporation and the branch belong to the same legal economic entity. As the branch pays interests and franchise fees to the general corporation, it does not pay provision for income tax to the host country. (3) The branch is not an independent legal entity. It is not necessary for the branch disclosing more financial information. Therefore, the branch can escape from the supervision of the host country easily. (4) According to the international tax practice, branches in foreign countries can use the losses to balance out the profits of the general corporation in the world. At the very beginning, branches are always in losses. Using the losses to balance out the profits of the general corporation can reduce the taxes of the general corporation in its residential country. (5) Avoid the international double taxation. Advantages of a child company include three aspects as follow. (1) The child company is a "legal resident", which can appreciate all preferences listed in tax convertions signed by the host country and other countries. The branch is a "non-legal resident", which can not appreciate the same preferences. (2) If the country where the mother company lives apples the tax exemption or indirect tax exemption, the double taxation issue can be avoided effectively. (3) The child company can appreciate the tax deferral. The multi-national corporation should make specific analysis based on practical conditions and makes choices.

\subsection{Perform tax avoidance by a transfer pricing mechanism}

The essence of multi-national corporations performing tax avoidance by transfer pricing is to transfer the profits from a high-tax area to a low-tax area. Main methods are: (1) Adjust child companies' product costs by transactions. (2) Adjust child companies' product costs by materials and parts. (3) Adjust and control profits by trading fixed assets, such as machines and equipments. (4) Adjust and control profits by supplying technologies, management, and ads. (5) Adjust and control profits by transferring virtual assets, usually in form of franchise fees. (6) Adjust and control profits by renting, usually in form of setting prices internally. (7) Adjust and control profits by loans. Control the flow of profits by controlling the interest rate of loans. (8) Adjust and control profits by management fees. (9) Adjust and control profits by cash flows. Produce bad debts in purpose and increase or decrease expenses in order to transfer profits.

\subsection{Take advantages over international tax conventions}

In order to avoid the international double taxation, relevant countries usually choose to sign bilateral conventions. In these conventions, contracting parties will make restraints or concessions. For example, decrease the rate of withholding tax imposed by the source country for the income gained there. Apply tax abatement or tax exemption for some items. Only the residents of contracting countries can appreciate these preferences. However, the residents of non-contracting countries can get benefits from the tax convention signed by the two countries by a delicate arrangement. For example, Japan and America sign a mutual preferential tax convention. Japanese banks can appreciate a $50 \%$ discount of rate of withholding tax as they get interests of loans from American residents. If similar businesses happen between a Chinese bank and an American company, namely the Chinese bank offering loans for the American company, the Chinese bank can entrust a Japanese bank to collect the interests from the American company since there is no similar regulations between China and America. By this way, the Chinese bank can pay less tax. See to the Figure 1 as follow.

\subsection{Actualize tax avoidance by international tax shelters}

Firstly form a special firm. Then transfer wealth, profits, and other incomes to the firm by virtual intermediary businesses and a transfer pricing mechanism, which can reduce or avoid the high taxes of the mother corporation or other child companies in the host countries. In general, by forming a trade company, a stock controlling company, a financial company, or a trust company in tax shelters, the multi-national corporation transfer its incomes gained in other areas to the company in international tax shelters, achieving the goal of reducing taxes or tax exemption. 


\subsection{Actualize tax avoidance by tax deferral}

The tax deferral means the country that uses the resident jurisdiction collects taxes by the principle of cash payment as its residential companies gets profits from foreign child companies. In other words, only when the mother company receives dividends from child companies, can it pay taxes to the country where it lives. Therefore, the mother company can delay the repatriation of profits by all means (such as transferring profits to the child company in tax shelters). Then, it can occupy these funds with no consideration.

\subsection{Reverse tax avoidance}

In common international tax avoidance, taxpayers usually choose to avoid entering high-tax areas and live in low-tax areas as much as possible. But in practice, taxpayers may choose to operate in high-tax areas in order to get some interests. That is the so-called reverse tax avoidance. The ultimate target of reverse tax avoidance is to gain more benefits by paying more taxes superficially. For example, due to the low-tax countries' exchange control, transfer the income to the mother company that lives in a high-tax country by transfer pricing. Or, if a country sets higher tax rates and the multi-national taxpayer predicts a war in the future there, the multi-national corporation will collect investments and profits (although tax costs are higher) as soon as possible in order to avoid more losses.

\section{References}

A.A.Groppelli. translated by Shen, Hibo. Corporate Finance. Shanghai: Shanghai People's Publishing House.

Chen, Yuyou \& Zhang, Chuanming. Corporate Financial Management. Beijing: China Financial \& Economic Publishing House.

Eugene F. Brigham \& Joel F.Houston..Fundamentals of Financial Management. Dalian: Dongbei University of Finance \& Economics Press.

Lu, Zhengfei \& Zhu, Kai. Advanced Financial Management. Hangzhou: Zhejiang People's Publishing House.

Mao, Fugen. Multinational Financial Management. Dalian: Dongbei University of Finance \& Economics Press.

Xia, Leshu \& Liu, Shulian. Corporate Finance. Beijing: China Financial \& Economic Publishing House.

(1) Loan

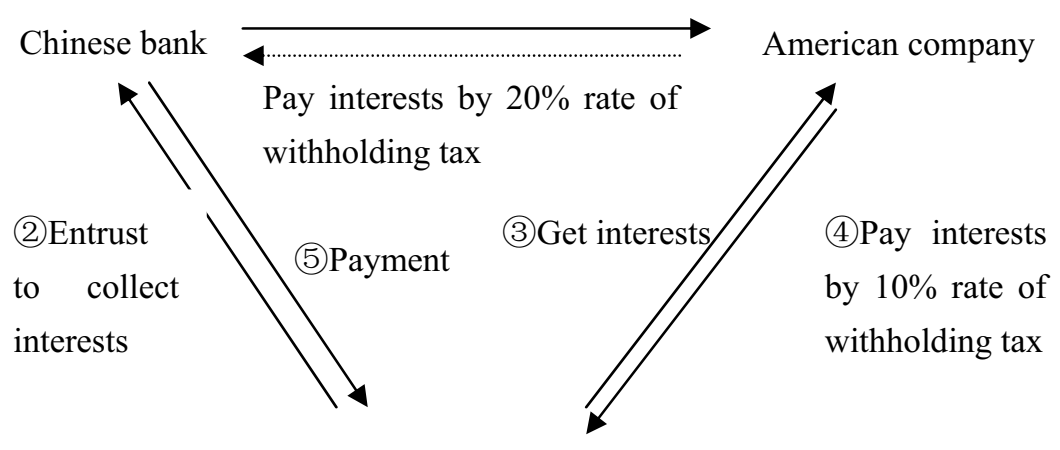

Japanese bank

Figure 1. 